\title{
THE ENDOGENOUS URIC ACID METABOLISM IN PERNICIOUS ANEMIA
}

\author{
By MATTHEW C. RIDDLE ${ }^{2}$
}

(From the Thomas Benry Simpson Memorial Institute for Medical Research, University of Michigan, Ann Arbor)

(Received for publication June 8, 1929)

The investigations of Rosenquist (1) and of Gibson and Howard (2) on the urinary excretion of endogenous uric acid and of Gettler and Lindeman (3) on the uric acid content of the blood in pernicious anemia suggest a disturbance of the purine metabolism in this disease. The results of these studies are characterized by their variability and by the frequency of abnormally high values for uric acid in the blood and urine of patients with pernicious anemia.

These investigations were performed before the discovery by Minot, Murphy, Cohn and their associates (4) (5) (6) (7) (8) of the specific therapeutic effect of liver and of extracts of liver in pernicious anemia. The remarkable improvement in patients following the daily ingestion of small amounts of liver extract suggests an association of the disease process with some unknown disorder of metabolism and indicates the importance of a reëxamination and reëvaluation of the existing knowledge of the metabolic manifestations of this disease.

Fortunately liver and liver extract, aside from their remedial value, provide a method for the experimental control of the course of the disease. Remissions may be produced at will and consequently may be anticipated for experimental purposes. This paper deals with the behavior of the endogenous uric acid metabolism during the early stages of remission in patients with pernicious anemia.

\section{MATERIAL AND METHODS}

The endogenous uric acid metabolism was studied over periods of ten to seventy-four days in twelve patients, eight men and four women,

${ }^{1}$ Fellow in Medicine of the National Research Council. 
and in one normal person, the latter serving as a control. Each patient exhibited the characteristic blood findings, symptoms and response to liver extract therapy which occur in pernicious anemia. In all patients free hydrochloric acid was absent from the gastric contents. None of these patients had used liver or liver extract recently enough or in sufficient quantities to modify the course of the disease, so all were observed during a relapse except one woman, who was seen first very early in a spontaneous remission.

Before treatment four of the twelve patients had red blood cell counts of less than $1,000,000$ per cubic millimeter; six had counts between 1,000,000 and 1,500,000; and two had counts between $1,500,000$ and 2,500,000. Of the twelve, six were in their first relapse, four in the second and one was in a fifth and one in a seventh relapse.

In each patient the various dietary constituents and the total caloric intake were known and recorded each day. To avoid exogenous sources of uric acid, purine-poor diets were used, from which foods containing nucleic acid compounds or purine derivatives such as meats, fish, peas, beans, tea, coffee and chocolate were excluded. The diets were otherwise limited only by the patient's appetite.

In general the use of drugs was avoided to prevent variations in uric acid excretion from this source although dilute hydrochloric acid was given to two patients in amounts of $12.0^{\circ} \mathrm{cc}$. daily without apparent influence on the uric acid metabolism.

Estimations of the amount of uric acid excreted each 24 hours in the urine were made throughout each period of observation. Frequent estimations of the uric acid content of the blood serum of fasting individuals were also made, in most patients every day. Serum rather than whole blood was used for this purpose to avoid the effect of the variation in the number of red blood cells since uric acid is distributed unequally between serum and cells.

In most patients, the daily excretion of other urinary constituents was determined. In all patients except one, the creatinine excretion was determined daily, since, being relatively constant in amount in the urine from day to day, creatinine serves as an index of accuracy of urine collection. In some patients, the daily urinary excretion of total nitrogen, urea nitrogen and ammonia nitrogen was studied. In others only the amount of total nitrogen excretion was determined. 
The method of Folin and Wu (9) (10) was used in urine uric acid determinations. The direct method of Folin-Beriedict (10) (11) was employed in the determination of uric acid in the blood serum. Folin's method (10) (12) was used in the estimation of creatinine in the urine. The colorimetric methods (10) (13) (14) (15) (16) of Folin, using the modified Nessler-Winkler reagent, were employed for the estimation of total nitrogen, urea nitrogen and ammonia nitrogen in the urine.

The cellular changes in the blood were carefully followed in each patient with daily determinations of the percentage of the reticulocytes and frequent estimations of the numbers of red and white blood cells and of the amount of hemoglobin (Sahli method) in the blood.

In all laboratory procedures the usual precautions were observed to insure accuracy.

Before treatment, each patient was usually studied for a period of one to five days to observe the character of the endogenous uric acid metabolism during relapse. Then liver extract ${ }^{2}$ was given, usually in doses of six vials daily (equivalent to 600 grams of liver). This experimental procedure was occasionally modified to demonstrate special features of the uric acid metabolism, which are discussed elsewhere. The data thus accumulated are too numerous to present in detail. Consequently, except when charts or tables are used to illustrate certain important points, the results are generally summarized.

\section{THE URIC ACID METABOLISM DURING RELAPSE}

With the method of estimation used (10) (11), the amount of uric acid found in 25 determinations on the blood serum of normal fasting persons varied from 3.3 to $4.7 \mathrm{mgm}$. per $100 \mathrm{cc}$. of serum, the average value being $3.9 \mathrm{mgm}$. per $100 \mathrm{cc}$.

The amount of uric acid in the blood serum of eleven fasting patients with pernicious anemia, is shown in table 1. These determinations were made during a relapse, before treatment was given and while the patients were using a purine-poor diet. Uric acid was present in less

${ }^{2}$ Commercial liver extracts were used, Lilly's Liver Extract No. 343 or ParkeDavis Liver Extract, except in two patients who were given a liquid extract of cod livers, manufactured by White Laboratories, Inc., Gloucester, Mass. A vial of liver extract represents 100 grams of fresh liver. 
than the normal concentration in the blood serum of six patients under these circumstances, in normal concentration in three patients, and in a concentration greater than normal in only two patients. In the patient who showed the greatest amount of uric acid in the blood serum, $12.5 \mathrm{mgm}$. per $100 \mathrm{cc}$. of serum, chronic nephritis was present which may explain the uric acid retention observed. In the other patient with an increased serum uric acid value, $7.1 \mathrm{mgm}$. per $100 \mathrm{cc}$. of serum, hyperthyroidism was present, the basal metabolic rate being +47 , and for a period of three days the patient was ill with an upper respiratory infection, his buccal temperature rising as high as $103.2^{\circ} \mathrm{F}$.

TABLE 1

Blood serum uric acid values in parnicious anemia before treatment

Milligrams of uric acid per $100 \mathrm{cc}$. of blood serum

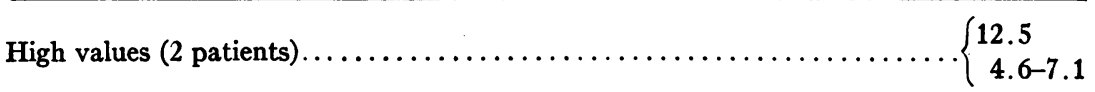

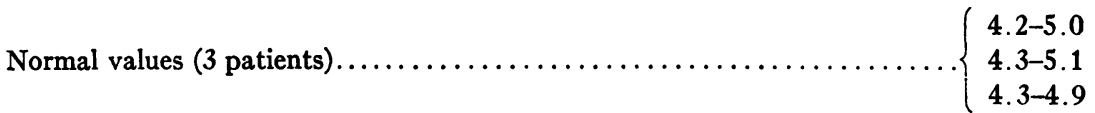

Low values (6 patients).............................

During the febrile period the elevated serum uric acid figure of 7.1 $\mathrm{mgm}$. per $100 \mathrm{cc}$. was obtained. Before this febrile disturbance serum uric acid values were within normal limits, being $4.6 \mathrm{mgm}$. per $100 \mathrm{cc}$. Also it is interesting to observe that, during the febrile period, this patient excreted abnormally large amounts of uric acid in the urine, 846 and $1488 \mathrm{mgm}$. of uric acid in two of the 24 hour periods. During other days the uric acid excretion was less than $600 \mathrm{mgm}$. per day. Figure 3 shows the findings on this patient.

With this one exception the daily urinary excretion of endogenous uric acid, in all patients on a purine-poor diet studied before treatment, was essentially normal, the daily excretion varying between 164 and 
$667 \mathrm{mgm}$. of uric acid. The amount of endogenous uric acid excreted normally each day is considered generally to vary between 200 and 600 mgm. In the normal person used as a control in this study, the daily excretion of endogenous uric acid, when liver extract was not given, was between 385 and $522 \mathrm{mgm}$.

From the analysis of these figures representing the endogenous uric acid excretion during relapse, no obvious abnormality of uric acid excretion appears to be present before treatment. In the case mentioned above, the increased excretion of uric acid was supposedly a result of hyperthyroidism and fever.

The amounts of uric acid in the blood serum were usually normal or less than normal before treatment. In only two cases were high values obtained and, in one of these, the factors of hyperthyroidism and fever were present, which probably augmented the amount of uric acid in the serum, and in the other chronic nephritis was present.

These results cannot be compared directly to those of Rosenquist (1), Gibson and Howard (2), and Gettler and Lindeman (3) who found the uric acid metabolism usually increased in pernicious anemia, since these investigators did not limit their observations to the period of complete relapse.

\section{THE URIC ACID METABOLISM DURING REMISSION}

A prompt and satisfactory response to liver extract treatment was observed in every patient. This was manifested in each case by the typical rise and fall in the percentage of reticulocytes during the first two weeks of treatment, by the steady increase in the numbers of red and white blood cells, and by the rapid clinical improvement which accompanies a remission in pernicious anemia. The remission was satisfactory in the two patients receiving cod liver extract, but was longer delayed than in the patients who were given the more effective liver extracts.

Very definite changes in the endogenous uric acid metabolism accompanied a remission in every patient. The response of the uric acid metabolism to liver extract treatment was characterized by an increased excretion of uric acid in the urine and by an increase in the concentration of uric acid in the blood serum. The response of the uric acid metabolism to treatment may be divided conveniently into 


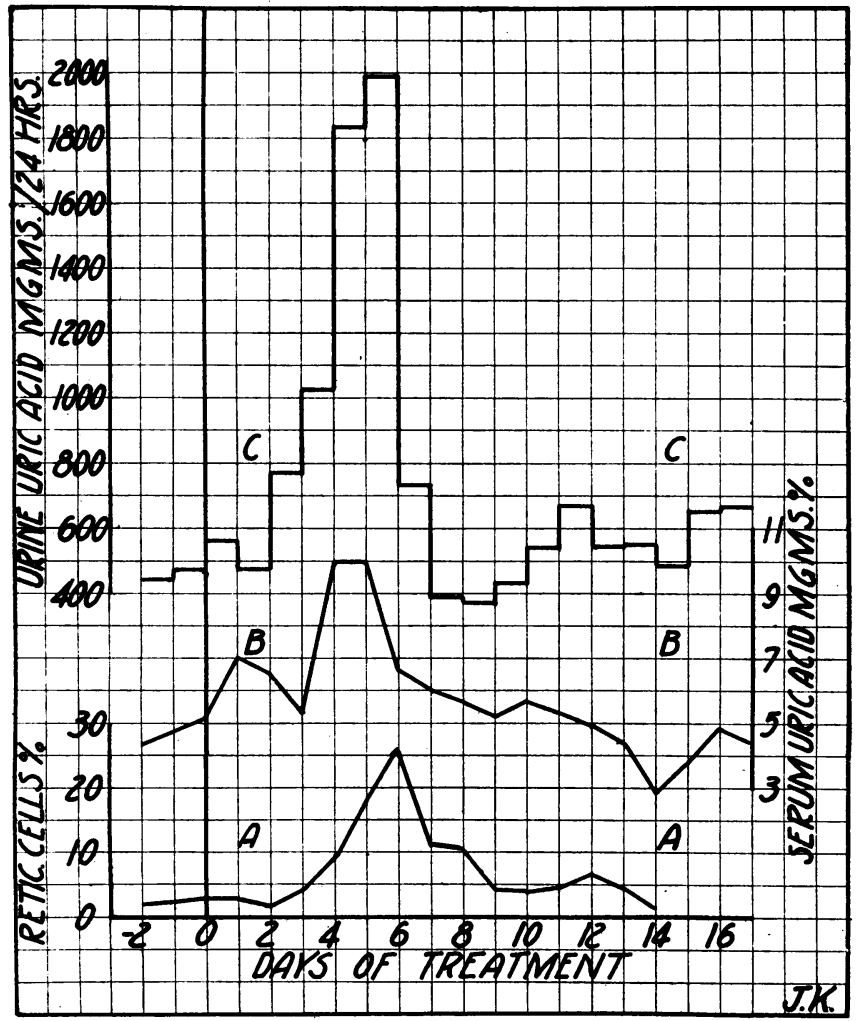

Fig. 1. Uric Acid Metabolism and Reticulocyte Percentage during EARLY REMISSION

Patient J. K. Before treatment red blood cells 1,070,000. Hemoglobin 22 per cent (Sahli). On the 18th day of treatment red blood cells 3,460,000. Hemoglobin 50 per cent (Sahli).

Treatment: 6 vials liver extract daily. Lilly's liver extract, No. 343. 0-4th day. Parke-Davis liver extract 4-17th day. Beginning of treatment is indicated by the vertical line.

$\mathrm{A}=$ percentage of reticulocytes.

$\mathrm{B}=$ concentration of uric acid in fasting blood serum in milligrams of uric acid per $100 \mathrm{cc}$.

$\mathrm{C}=$ urinary uric acid excretion in milligrams of uric acid per 24 hours. 
two phases. The first phase includes the first two weeks of treatment, during which the rise and fall in the percentage of reticulocytes occurs. It is characterized by a rise and fall in the amounts of uric acid in the blood serum and in the daily volumes of urine (see figs. 1 and 2). The

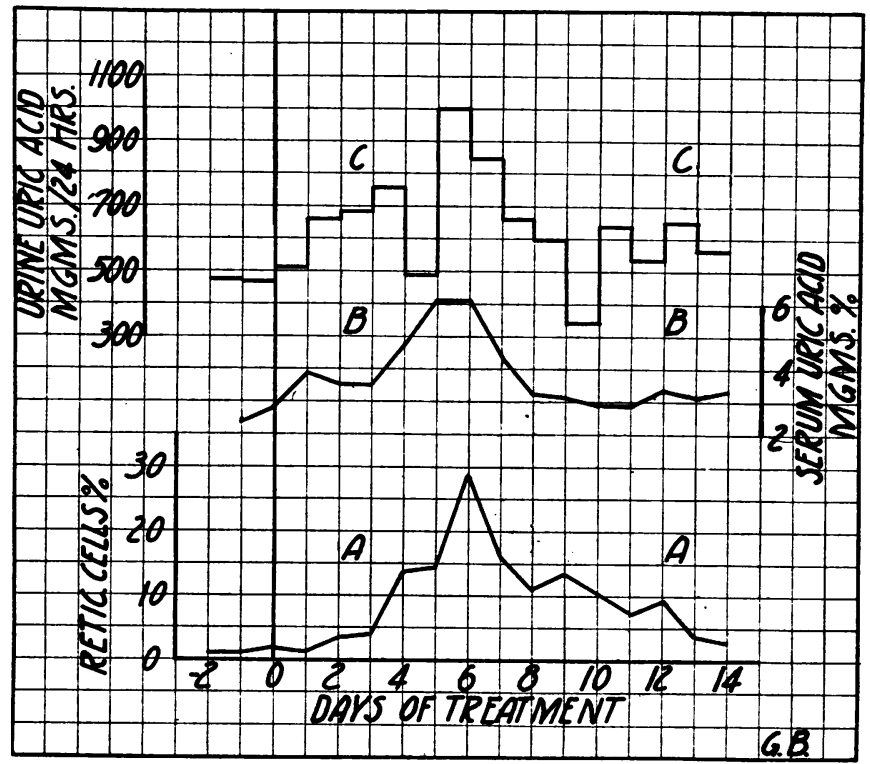

Fig. 2. Uric Acid Metabolism and Reticulocyte Percentage during EARLY REMISSION

Patient G. B. Before treatment red blood cells 1,310,000. Hemoglobin 25 per cent (Sahli). On the 13th day after treatment, red blood cells 2,350,000. Hemoglobin 51 per cent (Sahli).

Treatment: 6 vials of Lilly's liver extract No. 343 daily. The beginning of treatment is indicated by the vertical line.

$\mathrm{A}=$ percentage of reticulocytes.

$\mathrm{B}=$ concentration of uric acid in fasting blood serum in milligrams of uric acid per $100 \mathrm{cc}$.

$\mathrm{C}=$ urinary uric acid excretion in milligrams of uric acid per 24 hours.

second phase follows the reticulocyte response and occurs during the period of rapid blood regeneration. During this phase the concentration of uric acid in the blood serum and the daily excretion of uric acid rise again to an elevated level which is maintained, if liver extract 
therapy continues, for at least 60 days. Observations were not made over longer periods. These changes are illustrated by figure 3 .

The initial rise in the concentration of uric acid in the blood serum was apparent within 24 hours after liver extract was first given. The

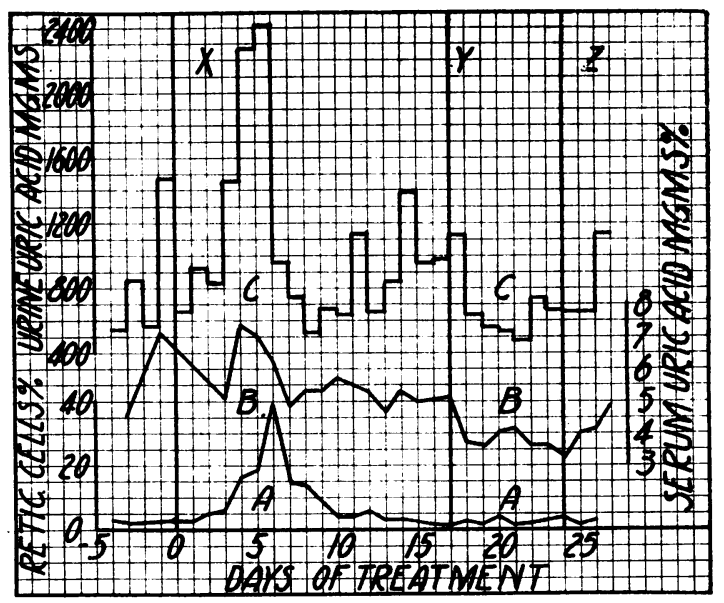

Fig. 3. The Effect of Liver Extract Medication on the Uric Acid Metabolism

Patient G. F. Before treatment red blood cells 860,000. Hemoglobin 19 per cent (Sahli). On the 26th day of treatment red blood cells 3,300,000. Hemoglobin 61 per cent (Sahli). This patient in addition to pernicious anemia had hyperthyroidism and, during the three days before treatment was begun, had fever from an influenzal upper respiratory infection.

Treatment Lilly's liver extract No. 343, 6 vials daily from $0-17$ th day and from 24th-28th day.

$\mathbf{A}=$ percentage of reticulocytes.

$\mathrm{B}=$ concentration of uric acid in the fasting blood serum in milligrams of uric acid per $100 \mathrm{cc}$.

$\mathrm{C}=$ urinary uric acid excretion in milligrams of uric acid per 24 hours.

$\mathrm{X}=$ beginning of liver extract treatment.

$\mathbf{Y}=$ liver extract treatment stopped.

$\mathrm{Z}=$ liver extract treatment resumed.

amounts of uric acid in the blood serum continued to increase for several days reaching maximal values after four to six days of treatment. There was then a decrease in the concentration of uric acid in 
the serum so that, at the end of fourteen days, the uric acid in the serum had returned to approximately the original amounts.

A similar rise and fall in the amounts of uric acid excreted each day in the urine was found during this period. A significant increase in the uric acid excretion was observed within two days, usually during the first day, following the first administration of liver extract. Maximal values were obtained between the fifth and seventh days. By the fourteenth day, the daily excretion of uric acid in the urine had returned to approximately its original level.

Exceptions to these observations occurred in only three patients. In them the same changes in the uric acid metabolism were observed but were delayed. Two of these patients received the less effective cod liver extract and the reticulocyte response was also delayed. In the third patient the initial red blood cell count was relatively high, being $2,490,000$ before treatment.

The maximum increase in the serum uric acid values during the first two weeks of treatment varied from 28 to 239 per cent. The actual increase, at the maximum, varied from 1.1 to $5.5 \mathrm{mgm}$. of uric acid per $100 \mathrm{cc}$. of serum. The maximal percentage increase in urine uric acid values varied from 74 to 531 per cent. The actual increase in urinary excretion varied from 386 to 1854 mgm. of uric acid per day during the days of greatest uric acid excretion. These figures clearly indicate the very marked increase in the uric acid metabolism which occurs during the first two weeks of treatment.

The fluctuations of the urinary uric acid excretion, of the concentration of uric acid in the serum and of the percentage of reticulocytes parallel one another closely during the first two weeks of remission. Even minor secondary rises in the percentage of reticulocytes are usually accompanied by similar increases in the uric acid values for the urine and serum. Close examination of the data indicates that changes in the amount of uric acid excreted in the urine are usually preceded by similar changes in the concentration of uric acid in the blood serum. Likewise fluctuations in the percentage of reticulocytes are preceded by similar fluctuations in the uric acid values for urine and serum. This sequence of events may be demonstrated in figure 1 . Here the first increase of uric acid in the serum occurs during the first day of treatment. Increased excretion of uric acid in the urine appears 
between the second and third day and the first rise in the percentage of reticulocytes occurs on the third day. A maximum amount of uric acid was present in the serum on the fourth day, the greatest amount of uric acid was excreted between the fifth and sixth day and the greatest percentage of reticulocyte appeared on the sixth day. The appearance of the highest percentage of reticulocytes on the day following the greatest uric acid excretion is a very constant finding.

Observations were terminated at the end of the first phase of the response of the uric acid metabolism in all but two patients, one patient being studied for a period of 70 days after treatment was started, the other for 28 days. The findings on the latter patient are shown (fig. 3) since the results in the both cases are similar. This patient had a recurrent hyperthyroidism, following an operation for exophthalmic goitre two and a half years before, and, during the period of observation preliminary to treatment suffered from an intercurrent upper respiratory infection of the influenzal type lasting three days, with fever reaching $103.2^{\circ} \mathrm{F}$. and a leucopenia. This illness apparently caused a disturbance of the uric acid metabolism with an increase in the uric acid in the blood serum and in the urine. However when this had subsided and liver extract treatment was instituted the uric acid metabolism in this patient was similar to that in other patients in every way. This patient shows the increase of the uric acid metabolism during the second phase of remission and the effect of discontinuing liver extract treatment. As the percentage of reticulocy.tes decreased the uric acid values for both urine and serum fell to their original levels but rose later when the reticulocytes had decreased to a normal percentage. On the seventeenth day of treatment when liver extract was discontinued, the concentration of uric acid in the blood serum and the daily rate of uric acid excretion decreased abruptly and remained at a low level until liver extract treatment was resumed. Then uric acid reappeared in increased amounts in both serum and urine. During the second phase of remission, that following the reticulocyte response, although the reticulocytes were not increased in percentage, the red blood cell count rose steadily, increasing from $2,260,000$ on the sixteenth day to $3,300,000$ on the twenty-sixth day.

The patient, whose findings are shown in table 2, showed certain 
TABLE 2

Uric acid values during liver extract treatment, ${ }^{*}$ according to direct and indirect methods of estimation.

Patient E. P.

\begin{tabular}{|c|c|c|c|c|c|c|}
\hline \multirow{2}{*}{$\underset{\text { treatment }}{\text { Day of }}$} & \multicolumn{3}{|c|}{ Serum uric acid } & \multirow{2}{*}{$\begin{array}{c}\text { Percentage } \\
\text { of } \\
\text { reticulocytes }\end{array}$} & \multirow{2}{*}{$\begin{array}{c}\text { Day of } \\
\text { treatment } \\
-\end{array}$} & \multirow{2}{*}{$\begin{array}{l}\text { Urine uric } \\
\text { acid }\end{array}$} \\
\hline & Method 1 & Method 2 & Method 3 & & & \\
\hline & $\begin{array}{l}\text { mgm. per } \\
100 \text { cc. }\end{array}$ & $\begin{array}{l}\text { mgm. per } \\
100 \text { cc. }\end{array}$ & $\begin{array}{l}\text { mgm. per } \\
100 \text { cc. }\end{array}$ & & & mgm. per day \\
\hline 0 & 12.5 & 12.3 & 11.8 & 4.5 & $0-1$ & $562 \dagger$ \\
\hline 1 & 13.8 & 13.8 & 12.7 & 4.1 & $1-2$ & 629 \\
\hline 2 & 16.0 & -16.0 & 13.1 & 3.0 & $2-3$ & 1,268 \\
\hline 3 & 12.7 & 12.7 & 11.4 & 5.2 & $3-4$ & 1,404 \\
\hline 4 & 12.5 & 12.5 & 11.1 & 16.3 & $4-5$ & 1,806 \\
\hline 5 & 13.1 & 13.1 & 11.6 & 24.7 & $5-6$ & 1,709 \\
\hline 6 & 13.8 & 13.8 & 11.4 & 27.5 & $6-7$ & 1,326 \\
\hline 7 & 11.4 & 11.4 & 9.8 & 24.9 & $7-8$ & 1,062 \\
\hline 8 & 10.4 & 10.4 & 8.7 & 16.9 & $8-9$ & 704 \\
\hline 9 & 8.1 & & 7.1 & 6.6 & $9-10$ & 768 \\
\hline 10 & 9.5 & 9.6 & 7.0 & 8.3 & $10-11$ & 740 \\
\hline 11 & 11.2 & 11.2 & 9.0 & 5.9 & $11-12$ & 1,534 \\
\hline 12 & 10.2 & 10.2 & 8.0 & 4.1 & $12-13$ & 932 \\
\hline 13 & 9.2 & 9.0 & 7.0 & 7.4 & $13-14$ & 603 \\
\hline 14 & 9.2 & 9.0 & 7.8 & 6.7 & $14-15$ & 857 \\
\hline 15 & 9.1 & 9.0 & 7.7 & 5.8 & $15-16$ & 649 \\
\hline 16 & 7.8 & 7.8 & 7.0 & 4.6 & $16-17$ & 571 \\
\hline 17 & 8.7 & 8.7 & 7.6 & 4.2 & $17-18$ & 539 \\
\hline 18 & 8.2 & 8.2 & 7.8 & 3.9 & $18-19$ & 620 \\
\hline 19 & 8.6 & 8.6 & 7.5 & 3.4 & $19-20$ & 650 \\
\hline 20 & 9.8 & 9.6 & 8.3 & 5.6 & $20-21$ & 705 \\
\hline 21 & 8.4 & 8.0 & 7.6 & 3.8 & $21-22$ & 797 \\
\hline 22 & 6.6 & 6.4 & 6.2 & 3.0 & & . \\
\hline
\end{tabular}

* Treatment-12 vials of Lilly's liver extract No. 343 per day for the first seven days of treatment. The dose was then decreased to six vials daily.

Methods of serum uric acid estimation:

No. 1. Folin-Benedict direct method (10) (11).

No. 2. Folin indirect method (11) using silver lactate.

No. 3. Morris-MacLeod indirect method (17) using zinc sulphate.

In all methods the Folin and Denis (10) (18) uric acid reagent was used to produce the color reaction.

† Estimated. Urine specimen incomplete.

unusual features. The serum uric acid value before liver extract was given was unusually high, $12.5 \mathrm{mgm}$. per $100 \mathrm{cc}$. Nevertheless there was, as usual, an increase, $16.0 \mathrm{mgm}$. of uric acid being present per 
$100 \mathrm{cc}$. of blood serum after two days of treatment. The decrease of uric acid in the blood after this maximal value was reached was greater in this case than in any other and, on the twenty-second day, there were only $6.6 \mathrm{mgm}$. of uric acid per $100 \mathrm{cc}$. of serum, which, although still more than found in normal serum was approximately half the

TABLE 3

Protein consumption, urinary nitrogen total and uric acid excretion during early remission

\begin{tabular}{|c|c|c|c|c|c|c|c|c|c|}
\hline \multirow{2}{*}{$\underset{\text { treatment }}{\text { Day of }}$} & \multicolumn{3}{|c|}{ Patient (C. S.) } & \multicolumn{3}{|c|}{ Patient (G. F.) } & \multicolumn{3}{|c|}{ Patient (J. K.) } \\
\hline & $\begin{array}{l}\text { Food } \\
\text { protein }\end{array}$ & $\begin{array}{c}\text { Total } \\
\text { urine } \\
\text { nitrogen }\end{array}$ & $\begin{array}{c}\text { Urine } \\
\text { uric acid }\end{array}$ & $\underset{\text { protein }}{\text { Food }}$ & $\begin{array}{c}\text { Total } \\
\text { urine } \\
\text { nitrogen }\end{array}$ & $\begin{array}{c}\text { Urine } \\
\text { uric acid }\end{array}$ & $\underset{\text { protein }}{\text { Food }}$ & $\begin{array}{c}\text { Total } \\
\text { urine } \\
\text { nitrogen }\end{array}$ & $\begin{array}{c}\text { Urine } \\
\text { uric acid }\end{array}$ \\
\hline & $\begin{array}{l}\text { grams } \\
\text { per day }\end{array}$ & $\underset{\text { per day }}{\text { grams }}$ & $\underset{\text { per day }}{\operatorname{mgm}}$ & $\underset{\text { per day }}{\operatorname{grams}}$ & $\underset{\text { per day }}{\text { grams }}$ & $\underset{\text { per day }}{\text { mgm. }}$ & $\underset{\text { per day }}{\operatorname{grams}}$ & $\begin{array}{c}\text { grams } \\
\text { per day } \\
\text { (average) }\end{array}$ & $\underset{\text { per day }}{\operatorname{mgm} .}$ \\
\hline $0-1$ & 65.9 & 9.10 & 751 & 29.9 & 9.92 & 655 & 37.7 & & 565 \\
\hline $1-2$ & 54.6 & 9.87 & 715 & 59.5 & 8.78 & 917 & 27.0 & & 473 \\
\hline $2-3$ & 70.5 & 10.42 & 723 & 50.6 & 4.65 & 823 & 29.8 & $6.29^{*}$ & 771 \\
\hline $3-4$ & 66.6 & 8.97 & 758 & 58.7 & 5.00 & 1,459 & 14.9 & & $1,016^{*}$ \\
\hline $4-5$ & 55.9 & $10.00^{*}$ & $418^{*}$ & 52.4 & 9.32 & 2,268 & 19.4 & & 1,829 \\
\hline $5-6$ & 73.4 . & 10.43 & 851 & 59.4 & 9.44 & 2,407 & 16.7 & & $1,993^{*}$ \\
\hline $6-7$ & 53.9 & 9.17 & 1,075 & 63.1 & 6.99 & 963 & 31.8 & $4.33^{*}$ & 725 \\
\hline $7-8$ & 64.3 & 8.80 & 1,058 & 66.0 & 7.48 & 740 & 49.6 & & 396 \\
\hline $8-9$ & 51.2 & 8.17 & 827 & 65.7 & 6.71 & 520 & 35.3 & & 383 \\
\hline $9-10$ & 54.9 & 9.28 & 652 & 69.8 & 8.21 & 684 & 36.2 & & 427 \\
\hline $10-11$ & 63.2 & 8.91 & 657 & 66.7 & 7.24 & 630 & 48.4 & 5.93 & 535 \\
\hline $11-12$ & 60.1 & 7.19 & 537 & 87.3 & 8.40 & 1,120 & 40.2 & & 672 \\
\hline $12-13$ & 63.4 & 7.63 & 708 & 80.0 & 6.15 & 643 & 39.1 & & 537 \\
\hline $13-14$ & 65.5 & 7.22 & 949 & 71.4 & 5.91 & 831 & 49.3 & & 541 \\
\hline $14-15$ & 67.2 & 8.73 & 781 & 66.4 & 8.33 & 1,391 & 54.5 & 5.17 & 489 \\
\hline $15-16$ & 65.3 & 9.00 & 825 & 78.2 & 7.74 & 952 & 35.0 & & 647 \\
\hline $16-17$ & & & & 71.8 & 7.60 & 986 & 50.5 & & 667 \\
\hline
\end{tabular}

* Estimated. Urine specimens incomplete.

amount present before treatment. The reason for the original high value in this patient was attributed to nephritis.

The variations in the uric acid metabolism during remission were independent of the protein metabolism. The amounts of protein ingested varied usually between 40 and 70 grams a day, usually tending to rise with the increase of appetite as remission advanced. There was a tendency towards nitrogen retention during remission, in spite of the increased excretion of uric acid nitrogen. No evident ab- 
normalities of nitrogen metabolism other than that of uric acid nitrogen was observed. The changes in uric acid metabolism were independent of protein intake, and urinary nitrogen excretion as is shown in table 3 , where the daily protein intake, the total urinary nitrogen excretion and the excretion of uric acid is listed for three patients.

Urine uric acid determinations were made by an indirect method (9) (10) using silver lactate for the isolation of uric acid.' A direct method for determination of the uric acid in serum was used, leaving these estimations open to the criticism that other substances than uric acid possibly were included in the values obtained. To avoid this criticism, in two patients (fig. 6 and table 2) the serum uric acid values were obtained by the direct method usually employed and by two indirect methods, the Folin method (11) using silver lactate and the Morris and MacLoed (17) method using zinc sulphate to isolate the uric acid in the serum for estimation. The results obtained indicate the fact that the fluctuations of the uric acid values depend upon changing amounts of uric acid in the blood serum and were not due to other substances. The results from the Folin methods, direct and indirect, were in close agreement. The zinc sulphate method gave lower figures, as is usually the case, but showed the same fluctuations found in the other two methods.

\section{THE ENDOGENOUS CHARACTER OF THE INCREASED URIC ACID METABOLISM}

Liver extract, which is known to contain considerable amounts of purine materials, ${ }^{3}$. conceivably might serve as an exogenous source of uric acid. Actually however, the purine materials in liver extract do not appear to influence the uric acid metabolism significantly. That this is true is shown by the following four experiments which demonstrate that the influence of the uric acid precursors in liver extract is of no particular significance in the increased excretion of uric acid which is observed during a remission.

${ }^{3}$ Figures on the purine nitrogen content of liver extract, available through the kindness of Dr. Oliver Kamm and Dr. E. A. Sharpe of Parke, Davis and Company, show that Parke-Davis Liver Extract contains 5.21 per cent purine nitrogen and Lilly's Liver Extract No. 343, 2.71 per cent purine nitrogen. 
In the first experiment the effect of liver extract on the uric acid metabolism of a normal person using a purine-poor diet was studied. After four days of preliminary observation, six vials of liver extract were given däily for ten days, observations being continued for three days after liver extract was discontinued. The results are shown in figure 4. No significant changes in the percentage of reticulocytes, in the urinary uric acid excretion or in the concentration of uric acid

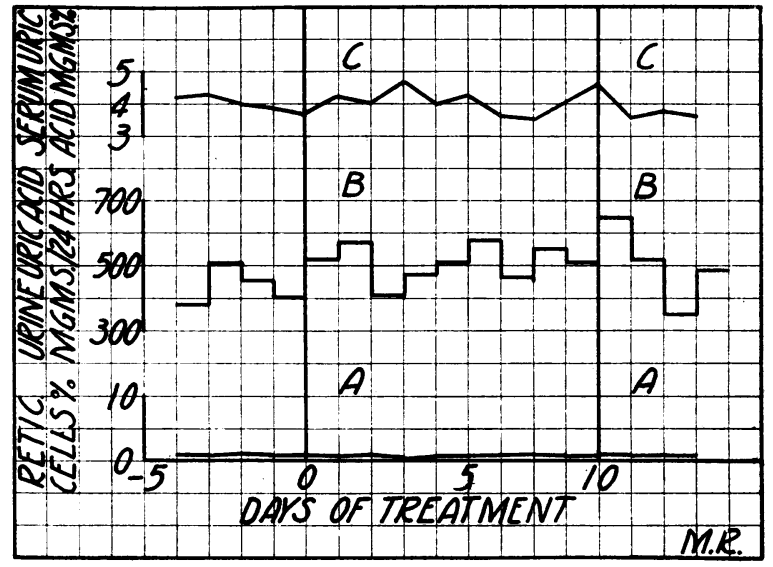

Fig. 4. The Effect of Liver Extract Medication on the Uric Acid Metabolism in a Normal Person

Normal person-M. R.

Treatment: 6 vials Lilly's liver extract No. 343 daily from 0-10th day. Vertical lines indicate beginning and end of liver extract therapy.

$\mathrm{A}=$ percentage of reticulocytes.

$\mathrm{B}=$ urinary uric acid excretion in milligrams of uric acid per 24 hours.

$\mathrm{C}=$ concentration of uric acid in fasting blood serum in milligrams of uric acid per $100 \mathrm{cc}$.

in the blood serum were observed. During the period of liver extract administration, the average daily excretion of uric acid exceeded that of the control periods by 79 milligrams, an amount which probably represents the increase due to the purine materials in liver extract.

The results of a second experiment are shown in figure 5. Here 30 vials of liver extract were given to a patient with pernicious anemia 
in a single day and no further medication was used during the experiment. A satisfactory remission was produced and the changes in the uric acid metabolism were identical to those obtained in patients who received six vials of liver extract daily, as may be seen by comparing

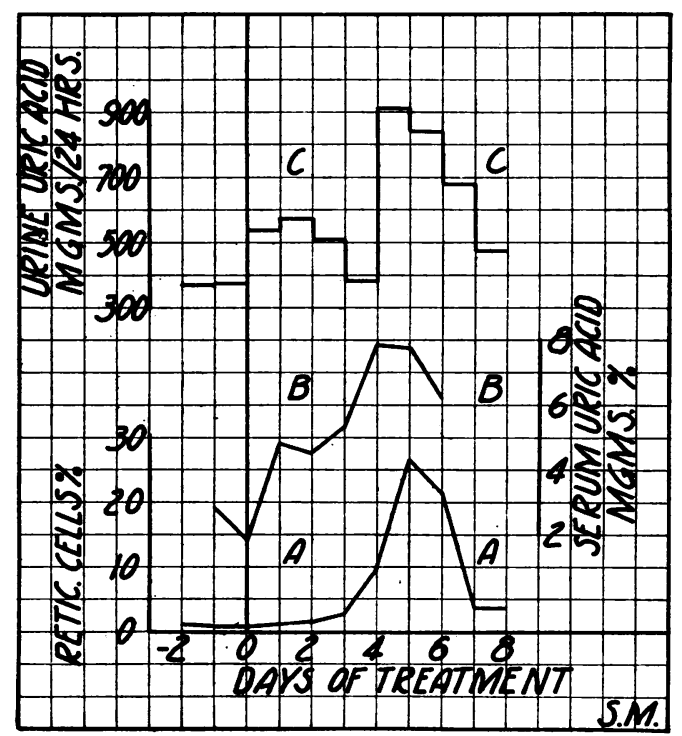

Fig. 5. Effect of a Massive Dose of Liver Extract on the Uric Acid Metabolism

Patient S. M. Before treatment red blood cells 1,120,000. Hemoglobin 29 per cent (Sahli). On 8th day of treatment red blood cells 1,630,000. Hemoglobin 27 per cent (Sabli).

Treatment: 30 vials Lilly's liver extract No. 343 given at 0 (vertical line). No further medication.

$\mathrm{A}=$ percentage of reticulocytes.

$\mathrm{B}=$ concentration of uric acid in the fasting blood serum in milligrams of uric acid per $100 \mathrm{cc}$.

$\mathrm{C}=$ urinary uric acid excretion in milligrams of uric acid per 24 hours.

figures 2 and 5. A great rise in uric acid excretion did not follow immediately after the liver extract was given, as would be expected had liver extract been an important source of uric acid precursors.

Liver extract which had been subjected to a pressure of 15 pounds 
and a temperature of $120^{\circ} \mathrm{F}$. for two hours in an autoclave $\mathrm{e}^{4}$ was given to a patient in daily doses of six vials in a third experiment. The

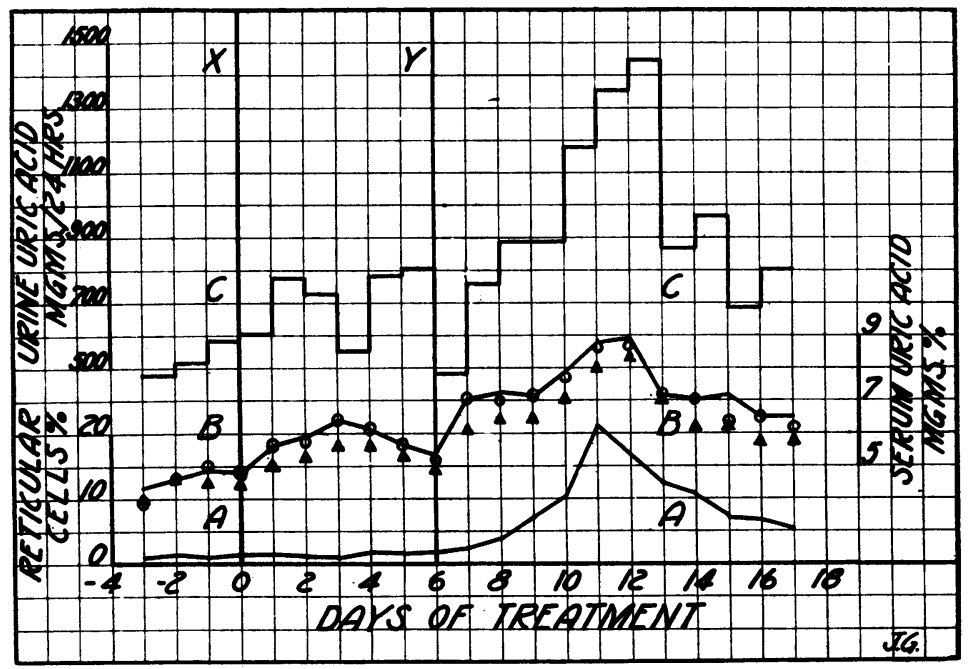

Fig. 6. Effect of Impotent (Heated) and Potent Liver Extract on the Uric Acid Metabolism

Patient J. G. Before treatment red blood cells 1,250,000. Hemoglobin 32 per cent (Sahli). On 17th day of treatment red blood cells 2,270,000. Hemoglobin 42 per cent (Sahli).

Treatment: 6 vials (24 grams) autoclaved Lilly's liver extract No. 343, daily 0-6th day. Unheated Lilly's liver extract 6 vials daily 6-17th day.

$\mathrm{A}=$ percentage of reticulocytes.

$\mathrm{B}=$ concentration of uric acid in fasting blood serum in milligrams of uric acid per $100 \mathrm{cc}$.

Heavy solid line-Folin direct method.

Open circles--Folin indirect method. (Silver lactate precipitation).

Solid triangles-Morris and MacLeod method (zinc sulphate precipitation).

$\mathrm{C}=$ urinary excretion of uric acid in milligrams of uric acid per 24 hours.

$\mathrm{X}=$ heated liver extract treatment begun.

$\mathrm{Y}=$ unheated liver extract treatment begun.

results are seen in figure 6 . The potency of the liver extract had apparently been impaired as a result of heating for there was no

"Mentioned through the kindness of Dr. Arthur Curtis, whose observations on this method of rendering liver extract ineffective are unpublished. 
significant increase in the percentage of reticulocytes. However a moderate increase in the concentration of uric acid in the blood serum and in the daily urinary excretion of uric acid occurred. After six days, potent, unheated liver extract was given in the same dosage of six vials daily. Then the usual rise in the percentage of reticulocytes and the usual rapid and great increase of uric acid in the serum and urine took place. This experiment indicates that the characteristic

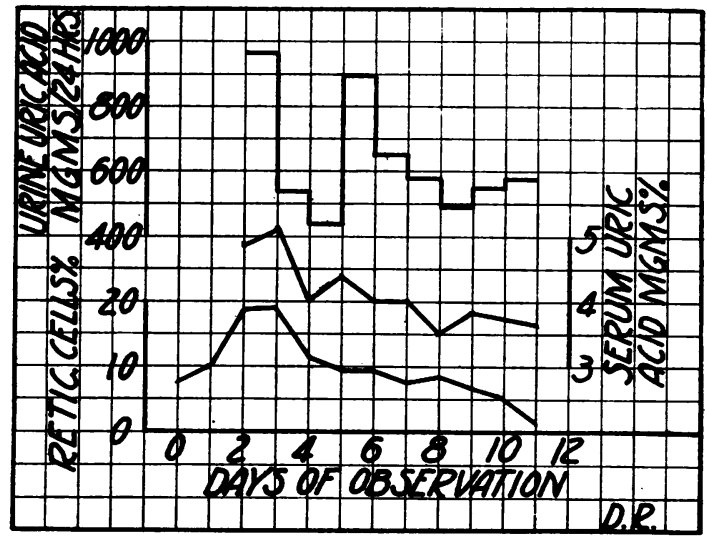

Fig. 7. The Uric Acid Metabolism during Spontaneous Remission

Patient D. R. On the first day of observation, red blood cells $1,020,000$. Hemoglobin 30 per cent (Sahli). On 12th day, red blood cells 1,760,000. Hemoglobin 37 per cent (Sahli).

Treatment: None. Spontaneous remission.

Lower curve $=$ percentage of reticulocytes.

Middle curve $=$ concentration of uric acid in fasting blood serum in milligrams of uric.acid per $100 \mathrm{cc}$.

Upper curve $=$ urinary uric acid excretion in milligrams of uric acid per 24 hours.

changes in the uric acid metabolism which are observed during remission are associated with the remission itself rather than with the feeding of exogenous sources of uric acid in the liver extract. Whether the heat to which the liver extract was subjected in this experiment alters the purine constituents of liver extract as well as the substance effective in pernicious anemia is not known. While this is considered improbable the existence of such a possibility must be recognized. Added evidence of the endogenous character of the increased uric 
acid metabolism during remission was fortunately obtained from a patient undergoing spontaneous remission. The increased urinary uric acid excretion and the elevated serum uric acid values, seen in patients in whom remission was induced by liver extract, were observed in this patient whose findings are shown in figure 7. This patient received no liver therapy before or during the period of observation.

These experiments furnish evidence of the endogenous character of the increased uric acid metabolism which accompanies remission in pernicious anemia.

\section{DISCUSSION}

An association between the increased activity of the hematopoietic tissues during early remission and the increased endogenous uric acid metabolism is suggested by the orderly manner in which the uric acid metabolism rises and falls with the rise and fall in the numbers of reticulocytes. The sequence of the appearance of increased amounts of uric acid first in the blood and then in the urine and finally of increased numbers of reticulocytes in the blood lends color to the belief that the increased uric acid metabolism is a physiological expression of the rapid maturation of red blood cells, which is an important feature of remission. The great numbers of red cell nuclei, lost during the maturation process as red blood cells in the bone marrow assume their non-nucleated form, may be an important source of the increased amounts of uric acid found in the blood and urine during early remission. Other factors, no doubt, also contribute to the elevated metabolism of purine substances. A generalized increase of nuclear metabolism throughout the body during remission seems worth mentioning as another factor possibly of importance.

The increase of the concentration of uric acid in the blood serum within 24 hours after the onset of treatment, precedes the reticulocyte increase by one or more days and furnishes the earliest laboratory evidence of oncoming remission.

From the experimental evidence, the increased uric acid metabolism appears to be associated with the act of a remission itself, rather than with increase protein consumption, with the manner in which remission is produced or with the presence of materials in liver extract which are theoretically capable of producing uric acid. 
SUMMARY

1. Before treatment, in patients with pernicious anemia in a complete relapse, using a purine poor diet, the concentration of uric acid in the fasting blood serum varies considerably but usually is normal or less than normal.

2. Normal amounts of uric acid are eliminated in the urine before treatment in uncomplicated cases.

3. The uric acid metabolism behaves in a very characteristic manner during early remission whether remission is spontaneous or is induced by liver extract. There is a prompt increase of the amounts of uric acid excreted, which is, as a rule, apparent within the first 24 hours of treatment.

4. During the first two weeks of treatment, the fluctuations of the uric acid metabolism follow those of the numbers of reticulocytes in the blood.

5. In the succeeding period, the uric acid metabolism rises to an elevated level which is maintained, within the periods of observation, as long as treatment continues.

6. The increased uric acid metabolism during early remission is endogenous in origin and is not accompanied by any outstanding abnormalities in the general nitrogen metabolism.

7. The destruction of large numbers of red blood cell nuclei which accompanies the rapid maturation of red blood cells and an increase in general nuclear metabolism throughout the body are advanced as factors which may contribute to the increased uric acid metabolism in pernicious anemia during early remission.

\section{BIBLIOGRAPHY}

1. Rosenquist, E., Ztschr. f. Klin. Med., 1903, xlix, 193. Ueber den Eiweissstoffwechsel bei der Perniciosen Anämie.

2. Gibson, R. B., and Howard, C. P., Arch. Int. Med., 1923, xxxii, 1. Metabolic Studies in Pernicious Anemia.

3. Gettler, A. O., and Lindeman, E., Arch. Int. Med., 1920, xxvi, 453. Blood Chemistry of Pernicious Anemia.

4. Minot, G. R., and Murphy, W. P., J. Am. Med. Assoc., 1926, lxxxvii, 470. Treatment of Pernicious Anemia by a Special Diet.

5. Minot, G. R., and Murphy, W. P., J. Am. Med. Assoc., 1927, lxxxix, 759. A Diet Rich in Liver in the Treatment of Pernicious Anemia. 
6. Minot, G. R., Murphy, W. P., Cohn, E. J., Stetson, R. P., and Lawson, H. A., Tr. Assoc. Am. Phys., 1927, xlii, 83. The Feeding of Whole Liver or an Effective Fraction in Pernicious Anemia. The Response of the Reticulocytes.

7. Cohn, E. J., Minot, G. R., Fulton, J. F., Ulrichs, H. F., Sargent, F. C., Weare, J. H., and Murphy, W. P., J. Biol. Chem. 1927, lxxiv, p. lxix. The Nature of the Material in Liver Effective in Pernicious Anemia. I.

8. Cohn, E. J., Minot, G. R., Alles, G. A., and Salter, W. T., J. Biol. Chem. 1928, lxxvii, 325. The Nature of the Material in Liver Effective in Pernicious Anemia. II.

9. Folin, O., and Wu, H., J. Biol. Chem., 1919, xxxviii, 459. A Revised Colorimetric Method for Determination of Uric Acid in Urine.

10. Folin, O., Laboratory Manual of Biological Chemistry. O. Appelton and Co., 1925. New York.

11. Folin, O., J. Biol. Chem., 1922, liv, 153. A System of Blood Analysis. Supplement IV. A Revision of the Method for Determining Uric Acid.

12. Folin, O., J. Biol. Chem., 1914, xvii, 469. On the Determination of Creatinine and Creatine in Urine.

13. Folin, O., and Denis, W., J. Biol. Chem., 1916, xxvi, 473. Nitrogen Determination by Direct Nesslerization. I. Total Nitrogen in Urine.

14. Folin, O., and Denis, W., J. Biol. Chem., 1916, xxvi, 501. Nitrogen Determinations by Direct Nesslerization. IV. Urea in Urine.

15. Folin, O., and Youngburg, G. C., J. Biol. Chem., 1919, xxxviii, 111. Note on the Determination of Urea in Urine by Direct Nesslerization.

16. Folin, O., and Bell, R. D., J. Biol. Chem., 1917, xxix, 329. Applications of a New Reagent for the Separation of Ammonia. I. The Colorimetric Determination of Ammonia in Urine.

17. Morris, J. L., and MacLeod, A. G., J. Biol. Chem., 1922, 1, 55. Colorimetric Determination of Uric Acid by a New Method.

18. Folin, O., and Denis, W., J. Biol. Chem., 1912, xii, 239. On Phosphotungsticphosphomolybdic Compounds as Color Reagents. 